\title{
"Design and Synthesis of Some Cyclic Carbohydrates with Norfloxacin as Surface moiety. A Study of Sustained Relax of Drugs".
}

\author{
J. DHEVARAJ, S. VEMBU, S. PAZHAMALAI* and M. GOPALAKRISHNAN \\ Department of Chemistry, Annamalai University, Annamalai Nagar 608002, Tamil Nadu, India. \\ *Corresponding author E-mail: sripazhamalai@gmail.com \\ http://dx.doi.org/10.13005/ojc/350211
}

(Received: July 15, 2018; Accepted: March 02, 2019)

\begin{abstract}
Biocompatible and biodegradable sustained drug delivery system has been constructed from reaction between norfloxacin and cyclodextrin through secondary amine of piperazine ring and hydroxyl group of the carbohydrate. Covalent bond polymeric structure is designed by the help of chloroacetyl chloride, target dendrimer formed by removing two hydrochloride molecules. The development of cyclodextrin core drug delivery system with twenty one norfloxacin surface moiety has been synthesized by only two steps. The synthesized polymeric structure was thoroughly studied by NMR, FT-IR, MALDI and UV-spectrometry. Sustained release assessment of synthetic polymer studied through different buffer solution by UV spectrometry and norfloxacin releases rate of synthetic polymer was controlled by the concentration and the experimental medium. The microbial assessments through kinetic studies by using Escherichia coli also reveal that the norfloxacin released possesses potential antimicrobial activity. Antibacterial activity of synthesized drug delivery system has been investigated with Gram-negative and Gram-positive species like Escherichia coli (mtcc 443), Bacillus subtilis (mtcc 2063), Pseudomonas (mtcc 741), Staphylococcus (mtcc 737) and proteus mirabilis (mtcc 425). The hydrophobic and hydrophilic balance and the repeat drug unit of this synthesized system are responsible for effective antibacterial activity. The minimum inhibitor concentration values of this system are very small to $100 \mu \mathrm{g} / \mathrm{mL}^{-1}$, synthesized compound shown five times improved activity against organism on comparism with standard drug. The in-vitro release of norfloxacin from obtained dendrimer was investigated.
\end{abstract}

Keywords: Norfloxacin, Cyclodextrin, Triethylamine, Chloroacetyl chloride, Tetrahydrofuran, Dimethyl sulfoxide.

\section{INTRODUCTION}

$\beta$-cyclodextrin and its derivatives are generally used in pharmacology as containers for some medicines owing to their unique property of encapsulating different hydrophobic compounds by formation of the inclusion compounds of guest-host type $^{1}$. Such encapsulation complex the included medicine from bio-decomposition, contributes to increase in its solubility and that is of considerable importance to effective and selective delivery of the medicine to the important place for a short time. However,

This is an Open Access article licensed under a Creative Commons license: Attribution 4.0 International (CC- BY). Published by Oriental Scientific Publishing Company @ 2018

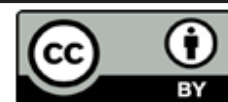


in the recent past much attention is paid to investigate the covalent binding or conjugation of a medicine to cyclodextrin that allows preparing new medicines with more prolonged and goal directed action. ${ }^{2}$

\section{Cyclodextrin-Assemblies}

The three member family of cyclic oligosaccharides called cyclodextrins (CDs) $(\alpha-, \beta-$, and $\gamma$-CDs), are linked by $\alpha-1,4$-glucopyranose units (Fig. 1). Hydrophobic inner cavity and hydrophilic outer surface is important feature in cyclodextrin, the shape resembling like a bridged cone. Cyclodextrin not only used to excellent receptor for molecular recognition, it is extensively used to fashionable building blocks for supramolecular assembly. The exceptional applications of cyclodextrins are due to (i) their soluble ability in aqueous medium (ii) it's action as receptor molecule to a broad variety of guest molecules and (iii) their well-defined molecular structure. ${ }^{3-7,8-12}$

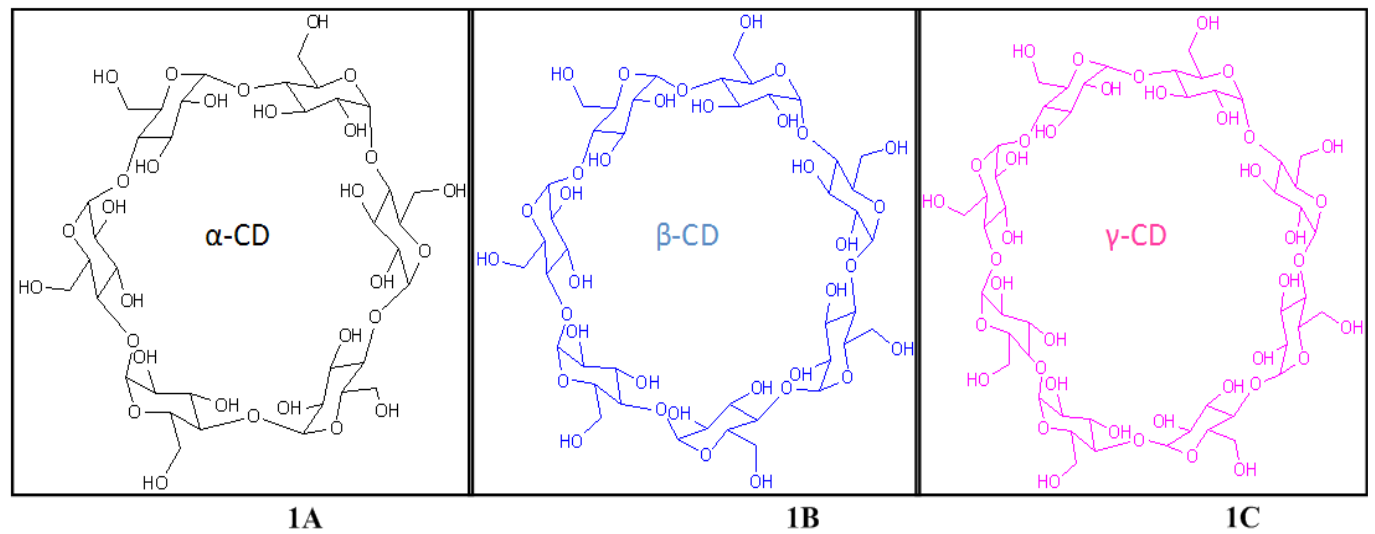

Fig. 1. Molecular structure of $\alpha, \beta$ and $\gamma$-cyclodextrin

\section{Norfloxacin}

Norfloxacin, a fluoroquinoline oral anti-biotic is active against pseudomonas aeruginosa and penicillin resistant strain of nisseria gonorrhoea. The drug is less active against Gram-positive cocci. Norfloxacin is inhibiting the subunits of DNA gyrase due to its bactericidal effect, which is essential for DNA replication of bacteria.

Based on the formerly mentioned findings, the important aim of this research is to design sustain drug delivery system with biodegradable artificial polymer with well define shape, monomeric properties and analogues to the protein have been known to literature as dendrimer. Theses synthesized drug delivery system almost in a spherical shape, the diameters normally from 2 to $10 \mathrm{~nm}$ with excellent novel and sustain drug delivery application system ${ }^{13,14}$ derivatives of norfloxacin for the purpose of improving the antimicrobial performance of norfloxacin and the control drug delivery system construction through covalent bond interaction. $\beta$-cyclodextrin is versatile platform to form spherical shape drug released system are architecture through covalent bond interaction between cyclodextrin and norfloxacin. The cells of $V$. parahaemolyticus have an energy dependent efflux system for drug molecule; they cloned a gene for a putative norfloxacin efflux protein from the chromosomal DNA of V. parahaemolyticus with an Escherichia colimutant lacking the major multidrug efflux system.

Cell based assay methods are important part of the synthetic organic field to evaluate the ability of biological activity. Antibacterial activity of synthesized compound tested against different bacteria or cancer cell and the synthesized compounds are inhibited their growth against sustain drug delivery. In this study, we examined the norfloxacin drug release of synthesized dendrimer by using Staphylococcus aureus (mtcc 737, Gram positive) and Escherichia coli (mtcc-443, Gram negative) microorganism.

\section{RESULTS AND DISCUSSION}

\section{Chemistry}

The twenty one number of hydroxyl group of narrower end primary (bonded to the C6 atoms) 
and broadest end secondary (bonded to the $\mathrm{C} 2$ and $\mathrm{C} 3$ atoms) hydroxyl groups in $\beta$-cyclodextrin core play an important role to design this drug delivery system structure. The delivery system with twenty one numbers of norfloxacin molecules in the place of hydroxyl groups as a surface moiety has been synthesized in two steps, in order to improve the activity and its sustained delivery of dendrimeric drug. In the first step, chloroacetyl $\beta$-cyclodextrin is synthesized by the reaction in between chloroacetyl chloride and $\beta$-cyclodextrin using $\mathrm{N}$-Ethyldiisopropylamine as a catalyst in tetrahydrofuran under refluxing condition. In this reaction, twenty one chloroacetyl chloride moieties are attached to $\beta$-cyclodextrin hydroxyl group. Further the norfloxacin and chloroacetyl $\beta$-cyclodextrin is mixed in the ratio of $1: 21$ to react under the above reaction condition gives the target molecule. In this, exactly twenty one piperazine of norfloxacin molecule react with twenty one chlorine groups of chloroacetyl $\beta$-cyclodextrin to form biodegradable norfloxacin dendrimer as the synthetic route is illustrated in Scheme 1.

Chloroacetyl norfloxacin was synthesized by mixing 1:21 ratio of norfloxacin and chloroacetyl chloride (NFLX, donated by Cipla Ltd, Bombay) was dissolved in $25 \mathrm{ml}$ tetrahydrofuran and then added $\mathrm{N}$-Ethyldiisopropylamine. The above mixture was refluxed to $8 \mathrm{~h}$, after completion of the reaction mixture was poured into ice water and the residue was extracted with ethyl acetate $(3 \times 50 \mathrm{ml})$. The combined ethyl acetate extracts were washed with water, Chloroacetyl norfloxacin separated as yellow colour fraction under reduced pressure. In the next step, 1:21 ratio of chloroacetyl $\beta$-cyclodextrin and norfloxacin react under the reaction condition to give the target molecule with good yield. The $\beta$-cyclodextrin suitable core moiety to construction of drug delivery system, it directly connected with twenty one chloroacetyl chloride groups, at the second stage twenty one norfloxacin moiety directly connected with chloroacetyl $\beta$-cd through covalent bond. Twenty one hydroxy groups are reacting with equal number of chloroacetyl chloride to form chloroacetyl $\beta$-cd by loss of $\mathrm{HCl}$ moleculs in the presence of base molecule. Twenty one piperazine of norfloxacin molecule replace with twenty one chlorine groups of chloroacetyl $\beta$-cyclodextrin to form norfloxacin moiety contain biodegradable system and the synthetic route of the norfloxacin drug delivery system is as illustrated in the Schemes 1 .

\section{EXPERIMENTAL}

The synthesized polymeric structure was involved systematically characterization through NMR, FT-IR, MALDI-TOF and UV-spectrometry. The vibrational spectra of the dendrimer were recorded in Agilent carry 630 spectrometry with a globar source, $\mathrm{Ge} / \mathrm{KBr}$ beam splitter and a MCT detector. Melting points were observed by the open capillary method and are uncorrected. ${ }^{1} \mathrm{H}$ and ${ }^{13} \mathrm{C}$ nuclear magnetic resonance (NMR) $(400 \mathrm{MHz}$; $\mathrm{CDCl}_{3}$ or DMSO) spectra were recorded at $293 \mathrm{~K}$ on BRUKER AVANCE III AMX-400 spectrometry operating frequencies of $400 \mathrm{MHz}$ for proton and 100 $\mathrm{MHz}$ for carbon using $\mathrm{CDCl}_{3}$ or DMSO as solvent. $5 \mathrm{mg}$ test sample was dissolved in $0.5 \mathrm{ml}$ of solvent $\left(\mathrm{CDCl}_{3}, \mathrm{DMSO}\right)$ to test solution preparation. All NMR Measurements were made on $10 \mathrm{~cm}$ NMR tubes and all the chemical shifts values are reported in parts per million scales ( $\delta$-scale) downfield from tetramethylsilane. MALDI-TOF mass spectrum was recorded on AB SCIEX TOF/TOF 5800. Sinapic acid was used as a matrix for all experiment. The matrix-samble ratio maintained at 100:1 throughought the experiments.

\section{Synthesis of chloroacetyl $\beta$-cyclodextrin and its spectral studies}

The newly purchased chemicals are used as it is to synthesis the target molecule. One millimole of $\beta$-cyclodextrin dissolved in tetrahydrofurane and adding twenty one millimole of chloroacetyl chloride in presence of triethyl amine. The reaction mixture was refluxed for 4-6 h, after completion of reaction; the reaction mixture was cooled to room temperature and poured into ice water. The final product was extracted with ethyl acetate and the chloroacetyl $\beta$-cyclodextrin fraction separated by reduced pressure method. Obtained fraction was used to different characterization and further stages. The IR spectrum of compound 2 in $(\mathrm{KBr})$ : acetyl ketone appeard at $1756 \mathrm{~cm}^{-1}(\gamma \mathrm{C}=\mathrm{O})$ and $2961 \mathrm{~cm}^{-1}$ for aliphatic $\gamma \mathrm{C}-\mathrm{H} .{ }^{1} \mathrm{H}$ NMR $\left(\mathrm{CDCl}_{3}, \mathrm{TMS}^{\mathrm{T}}, 27^{\circ} \mathrm{C}, 400\right.$ $\mathrm{MHz}) \delta 3.57$ (d, second carbon $\mathrm{CH}$ proton), $\delta 3.603$ (d, fourth carbon proton of glucopyranose ring). $\delta 4.1$ (fifth carbon proton of glucopyranose ring ), $\delta 4.25$ (third position carbon proton of glucopyranose ring) 
4.72 (sixth position proton of glucopyranose) and $\delta$ $5.57\left(-\mathrm{CH}_{2}\right.$ protons of acetyl chloride $) \cdot{ }^{13} \mathrm{C} \mathrm{NMR}\left(\mathrm{CDCl}_{3}\right.$, TMS, $\left.27^{\circ} \mathrm{C}, 400 \mathrm{MHz}\right) \delta 62.12$ (sixth position carbons of glucopyranose unit), $\delta 29.59$ (second position carbon). $\delta 44.90$ (third position carbon), $\delta 66.10$ (first carbon signal of glucopyranose ring), $\delta 42.30$ (fifth carbon in glucose ring), $\delta 32.84$ (fourth carbon of clucopyranose residue), $\delta 65.48$ (acetyl chloride carbon) and $\delta 170.81$ (acetyl chloride $\mathrm{C}=\mathrm{O}$ ).

Synthesis of norfloxacin based $\beta$-cyclodextrin core drug delivery system (compound-3) and its spectral studies

One millimole of chloroacetyl $\beta$-cyclodextrin and twenty one millimole of norfloxacin are dissolved in tetrahydrofuran in presence of $\mathrm{N}$-ethyldiisoprophylamine. The reaction mixture was refluxed for 4-5 h, after completion of the reaction mixture cooled to room temperature and then poured in ice water. The final product was filtered, dried and used for different charecterization including biological studies. The IR spectrum of compound in $(\mathrm{KBr})$ : acetyl ketone appeard at $1726(\gamma \mathrm{C}=\mathrm{O}), 1629$ ( $\gamma \mathrm{C}=\mathrm{O}$ cyclic ketone), $3441(\gamma-\mathrm{OH}$ of acid group), $1502(\gamma \mathrm{C}=\mathrm{C}$ aromatic ring) $3060(\gamma \mathrm{C}-\mathrm{H}$ aromatic), $2852-2922(\gamma \mathrm{C}-\mathrm{H}$ aliphatic). Mass spectrum of synthesized compound, molecular ion peak is $\mathrm{m} / \mathrm{z}$ 8262.0102. ${ }^{1} \mathrm{H}$ NMR (DMSO, TMS, $\delta, 400 \mathrm{MHz}$ $\left.27^{\circ} \mathrm{C}, 400 \mathrm{MHz}\right), 1.709\left(\mathrm{t}, 3 \mathrm{H}, \mathrm{CH}_{3}\right.$ protons of ethyl groups) $\mathrm{J}=4.0 \mathrm{~Hz}$ ), $1.757(\mathrm{~d}, 2 \mathrm{H}$, glugopyranose ring $\mathrm{C}_{6}$ carbon protons) $\mathrm{J}=6.4 \mathrm{~Hz}$ ) 2.494 (t $2 \mathrm{H}$ piprazine ring $\mathrm{CH}_{2}$ protons near to $\mathrm{cd}$ ) $\mathrm{J}=2.0 \mathrm{~Hz}$ ) 3.398 (s, 2H, acetyl group $\mathrm{CH}_{2}$ protons), 3.648 (t, $2 \mathrm{H}$, piperazine ring $\mathrm{CH}_{2}$ protons) $\mathrm{J}=2.0 \mathrm{~Hz}$ ) 3.985 (d, $2 \mathrm{H}$, glucopyranose ring $\mathrm{C}_{1}$ Carbon protons), $\mathrm{J}=5.2 \mathrm{~Hz}), 4.089\left(\mathrm{~m}, 1 \mathrm{H}\right.$, glucopyranose ring $\mathrm{C}_{5}$ carbon proton) $\mathrm{J}=5.2), 4.122(\mathrm{~m}, 1 \mathrm{H}$, glucopyranose ring $\mathrm{C}_{3}$ carbon proton) $\left.\mathrm{J}=6.8 \mathrm{~Hz}\right) 4.555(\mathrm{~m}, 2 \mathrm{H}$, glucopyranose ring $\mathrm{C}_{4}$ carbons protons) $\mathrm{J}=7.6 \mathrm{~Hz}$ ), $4.574\left(\mathrm{~m}, 2 \mathrm{H}\right.$, ethyl $\mathrm{CH}_{2}$ protons) $\left.\mathrm{J}=6.8 \mathrm{~Hz}\right) 4.609$ ( $\mathrm{m}, 1 \mathrm{H}$, glucopyranose ring $\mathrm{C}_{2}$ carbon Protons), $7.170\left(\mathrm{~d}, 1 \mathrm{H}\right.$, norfloxacin $\mathrm{C}_{8}$ carbon protons) $\mathrm{J}=7.2 \mathrm{~Hz}), 7.934\left(\mathrm{~d}, 1 \mathrm{H}\right.$, norfloxacin $\mathrm{C}_{5}$ carbon protons) $13.6 \mathrm{~Hz}) 8.946\left(\mathrm{~s}, 1 \mathrm{H}\right.$, norfloxacin $\mathrm{C}_{2}$ carbon proton), 15.381 (s, $1 \mathrm{H}$, norfloxacin acid proton). ${ }^{13} \mathrm{C}$ NMR (DMSO, TMS, $27^{\circ} \mathrm{C}, 400 \mathrm{MHz}, \delta$, ppm) 25.61 (glucopyranose ring $\mathrm{C}_{4}$ carbon), 51.53 (ethyl $\mathrm{CH}_{2}$ carbon) 14.30 (ethyl $\mathrm{CH}_{3}$ carbon), 58.11 (piperazine ring $\mathrm{CH}_{2}$ carbon near to norfloxacin), 59.55(acetyl group $\mathrm{CH}_{2}$ carbon attached with glucopyranose ring). 63.20 (glucopyranose residue $\mathrm{C}_{6}$ carbon), 166.12 (acid group ketone), 169.94 (acetyl group ketone), 176.14 (norfloxacin ring ketone) 137.17 (norfloxacin
C9 carbon), 148.45 (norfloxacin C2 carbon), 44.9763.20 (glucopyranose ring corbon), 105.87 - 148.45 (Fluorine attached norfloxacin ring).

HSQC (DMSO, TMS, $27^{\circ} \mathrm{C}, 400 \mathrm{MHz}$ ) spectral correlations like $\delta 42.5$ correlated with $\delta$ $4.11 ; \delta 2.53$ correlated with $\delta 40.6 ; \delta 207.1$ (>C=O) and 170.1 (ipso carbon); 8.28 ppm corresponding to $1.86 \mathrm{ppm}$; $52.57 \mathrm{ppm}$ correlated with $2.86 \mathrm{ppm}$; 35.34 ppm correlated with 3.56 ppm; 49.67 ppm correlated with $3.47 \mathrm{ppm}$ and the peak at 60.93 ppm correlated with $4.207 \mathrm{ppm}$, confirms the title compound formation.

$$
\begin{gathered}
\mathrm{B}-\mathrm{CD}+(\mathrm{CAC})_{21} \underset{\mathrm{Reflux}}{\stackrel{\mathrm{N}-\mathrm{EDPA} / \mathrm{THF}}{\longrightarrow}} \beta-\mathrm{CD}(\mathrm{CAC})_{21}+\mathrm{NOR} \underset{\mathrm{Reflux}}{\stackrel{\mathrm{N}-\mathrm{EDPA} T H F}{\longrightarrow}} \beta-\mathrm{CD}(\mathrm{CAC}-\mathrm{NOR})_{21} \\
\text { Scheme 1. Synthesis of chloroacetyl } \beta \text { - cyclodextrin and } \\
\text { Norfloxacin dendrimer with } \beta \text { - cyclodextrin }
\end{gathered}
$$

Table 1. Physical properties of compound 3

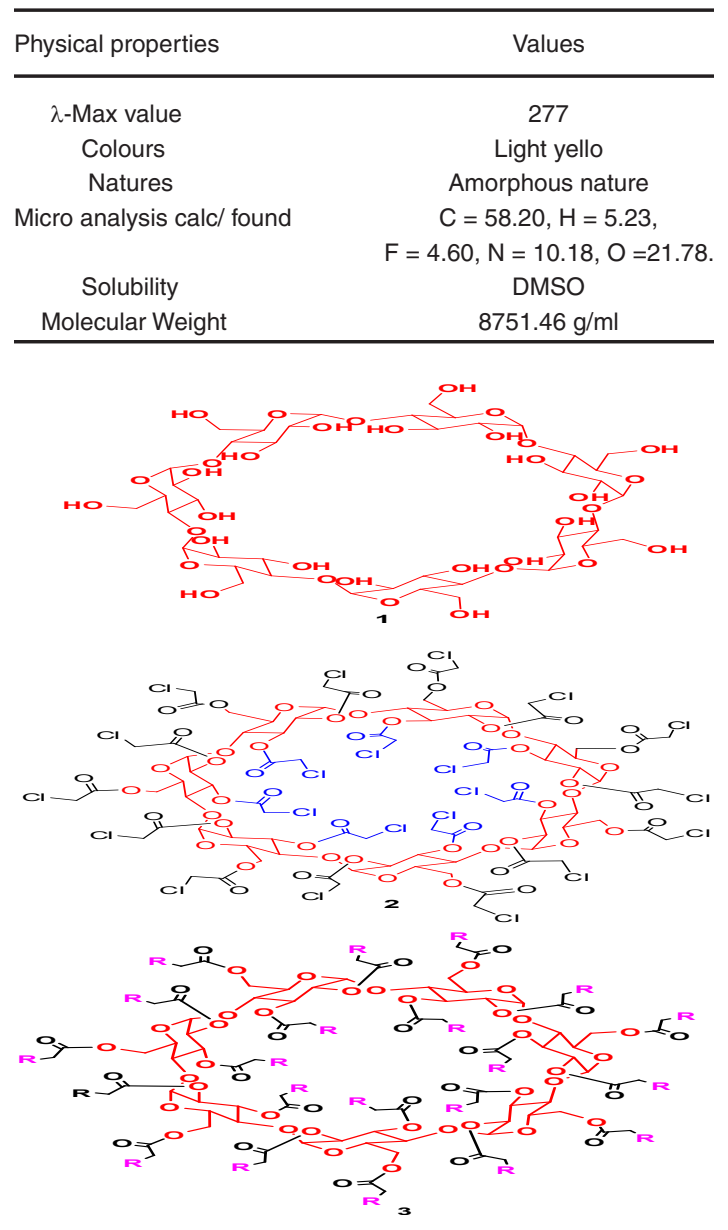

Fig. 2.Chemical structure of $\beta$-cyclodextrine(1), chloroacetyl $\beta$-cyclodextrine(2) and $\beta$-cyclodextrin core dendrimer(3) 
Synthesis of compound5(chloroacetyl $\alpha$-cyclodextrin) and its spectral studies

About $0.0011 \mathrm{~mol}$ of $\alpha$-cyclodextrin dissolved in tetrahydrofuran, to the above solution $2.24 \mathrm{mmol}$ of chloroacetyl chloride and N- Ethyldiisopropylamine were added, the reaction mixture was refluxed for 5-6 $\mathrm{h}$ at $70^{\circ} \mathrm{C}$ and also the reaction status was monitor by thin layer chromatography. After completion of the reaction, the mixture was poured in ice water and the product (chloroacetyl $\alpha$-cyclodextrin) separated by low pressure distillation method. Light yellow color semi solid was obtained, before to continue further stages the compound was characterized by IR spectral studies. Presence of carbonyl group stretching frequency at $1739.9 \mathrm{~cm}^{-1}$ confirmed the chloroacetyl group. Absence of $-\mathrm{OH}$ stretching frequencies conformed that all the hydroxyl group involved in ester formation, this ester bond formation is very useful to drug released study through hydrolysis reaction in aqueous solution with acidic condition.

\section{Synthesis of compound 6 (norfloxacin based $\alpha$-cyclodextrin core drug delivery system) and its spectral studies}

A mixture of $4.3 \mathrm{mmol}$ chloroacetyl $\alpha$-cyclodextrin, $2.25 \mathrm{mmol}$ norfloxacine, $25 \mathrm{ml}$ dimethyl sulfoxide and catalytic amount of $\mathrm{N}$-Ethyldiisopropylamine was refluxed at $190^{\circ} \mathrm{C}$ for 5-6 h, after completion of the reaction the mixture was poured into ice water, filtered and dried. The compounds are characterized using IR, UV, ${ }^{1} \mathrm{H}$ and ${ }^{13} \mathrm{C}$ NMR. Glucopyranose ring proton appeared from 2.50 to $3.80 \mathrm{ppm}, \mathrm{C}_{1}$ carbon attached protons chemical shift value is $3.8 \mathrm{ppm} . \mathrm{C}_{2}$ carbon attached protons appeared at $4.1 \mathrm{ppm} . \mathrm{C}_{3}$ carbon attached protons appeared at $3.33 \mathrm{ppm}, \mathrm{C}_{6}$ carbon attached protons appeared at $2.78 \mathrm{ppm}, \mathrm{C}_{5}$ carbon attached protons appeared at $2.5 \mathrm{ppm} \mathrm{C}_{4}$ carbon attached protons appeared at $2.54 \mathrm{ppm} . \mathrm{C}_{2}$ carbon attached proton downfield chemical shift value than other glugopyranose ring protons due to less shielding effect. Acetyl group methylene protons appeared at $2.50 \mathrm{ppm}$, norfloxacin ethyl group $\mathrm{CH}_{3}$ protons appeared at $1.18 \mathrm{ppm}$ and $\mathrm{CH}_{2}$ protons appeared at $1.31 \mathrm{ppm}$. norfloxacin aromatic protons appeared from 7.54 to $8.64 \mathrm{ppm}$, acid group $\mathrm{OH}$ proton appeared at $15.20 \mathrm{ppm}$.

The glucopyranose ring carbon appeared from 40.5 to $106.1 \mathrm{ppm}, \mathrm{C}_{1}$ carbon appeared at 106.1 ppm, $C_{2}$ carbon appeared at 60.3 ppm, $C_{5}$ carbon appeared at 58.6, $\mathrm{C}_{3}$ carbon appeared at 52.0 ppm, $\mathrm{C}_{6}$ carbons appeared at 50.8. The acetyl $\mathrm{CH}_{2}$ carbon appeared at $49.8 \mathrm{ppm}$, piperazine ring carbons appeared at 45.6 and 50.8 ppm, norfloxacin ethyl $\mathrm{CH}_{3}$ carbon appeared at $14.8 \mathrm{ppm}$. Norfloxacin aromatic carbon appeared from 111.70 to 154.7 ppm. norfloxacin ring unsaturated carbonyl carbon appeared at 176.80 ppm, ester carbonyl carbon appeared at 170.36, aced group carbonyl carbon appeared at $166.42 \mathrm{ppm}$, drug delivery system formation conformed by three carbonyl chemical shift appearance. Piperazine ring two chemically environment carbons appeared at 52.0 and 58.6 ppm, norfloxacin near carbons have less chemical shift values than other two carbons due to th eless shielded environment of the carbon. Acid attached and carbonyl presented ring carbons appeared from 107.1 to $148.92, C_{2}$ carbon have higher chemical shift value than other carbon of the ring due to less shielded, $\mathrm{C}_{3}$ carbon have less chemical shift value due to acid and carbonyl and ring pi electron strongly shielded, Fluorine attached ring carbons from 106.1 to 152.2 ppm, $C_{8}$ carbon have up field due to pi electron shielding, fluorine attached carbon have downfield due to fluorine reduced the electron density so carbon is less shielded.

The norfloxacin $\mathrm{OH}$ stretching frequencies appeared at $3414.2 \mathrm{~cm}^{-1}$, carbonyl group stretching frequencies appeared in the region of $1720 \mathrm{~cm}^{-1}$, Aromatic stretching frequencies $3019 \mathrm{~cm}^{-1}$ is conformed that presence of norfloxacin, symmetric and asymmetric aliphatic stretching frequencies appeared at $2848 \mathrm{~cm}^{-1}$ and $2954 \mathrm{~cm}^{-1}$. From the UV studies $\lambda$ max value $277 \mathrm{~nm}$ obtained is equal to norfloxacin value and the increasing $\mathrm{pH}$ range experiences hypochromic shift and the decreasing $\mathrm{pH}$ leads to hyperchromic shift.

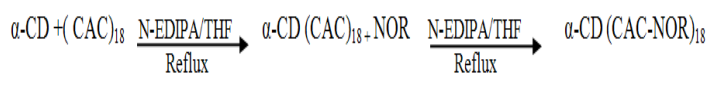

Scheme 2. Synthesis of compound 5 (chloroacetyl $\alpha$-cyclodextrin) and 6 (Norfloxacin based $\alpha$ - cyclodextrin core drug delivery system)

\section{MALDI TOF Characterization of compound- 3}

MALDI-TOF MS spectrum was used for the determination of molecular mass and the nature of end groups. ${ }^{15,16}$ MALDI-TOF MS show the number of fragment peaks to synthesized drug delivery system. The most prominent peaks appeared is characterized by fragmentation of different unit 
from the constructed dendrimer. In total six peaks are appeared at $8262.0102 \mathrm{Da}, 7129.1543 \mathrm{Da}$, 6093.1653Da, 4290.6234Da, 3690.7294Da and $2573.5643 \mathrm{Da}$ in that manner. The molecular ion peak is appeared at 8262.0102 Da (equal to mother ion molecular mass) confirms the formation of titled dendrimer. The expected molecular ion peak value is $8751.10 \mathrm{Da}$. the polymer unit NOR-CAC mass is 362.33, which unit assign the different fragmentation the twenty one unit are connected with $\beta$-cyclodextrin through covalent bond which unit are responsible for different fragment peaks.

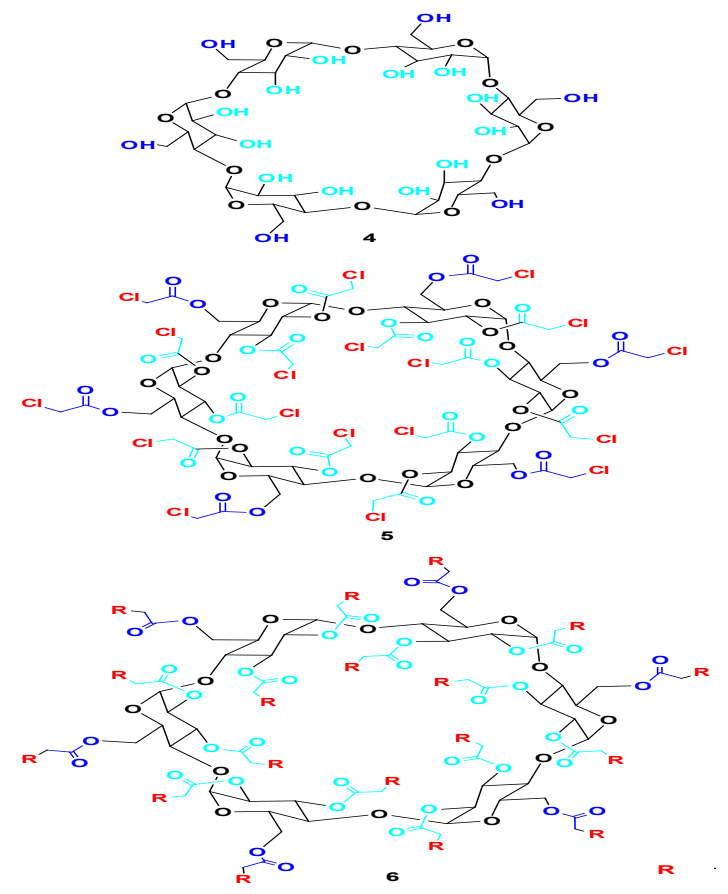

Fig. 3.Chemical structure of $\alpha$-cyclodextrine (4), chloroacetyl $\alpha$-cyclodextrine (5) and $\beta$-cyclodextrin core dendrimer (6)

The molecular ion peak at 8262.01 Da matching to oligomers doped with $\mathrm{H}+$ of type $\left(\mathrm{C}_{395}\right.$, $\left.\mathrm{H}_{418}, \mathrm{~F}_{19}, \mathrm{~N}_{57}, \mathrm{O}_{112}\right)$. The mass peak value at 7129.15 Da corresponding to oligomers doped with $\mathrm{H}^{+}$of type $\left(\mathrm{C}_{347}, \mathrm{H}_{368}, \mathrm{~F}_{16}, \mathrm{~N}_{48}, \mathrm{O}_{104}\right)$. The fragment peak appeared at 6093.16Da, matching to oligomers doped with $\mathrm{H}^{+}$ion of $\left(\mathrm{C}_{283}, \mathrm{H}_{304}, \mathrm{~F}_{12}, \mathrm{~N}_{36}, \mathrm{O}_{92}\right)$ the above values are confirmed that the norfloxacin fragment generated from drug complex. The peak appeared at 4290.62 (expected value for the fragment is 4323.03) is corresponds to oligomers doped with $\mathrm{H}^{+}$fragment mass $\left(\mathrm{C}_{203}, \mathrm{H}_{224}, \mathrm{~F}_{7}\right.$, $\mathrm{N}_{21}, \mathrm{O}_{77}$ ). The peak ranging from $3690.72 \mathrm{Da}$ and 2573.56 Da are corresponds to molecular mass of
$\left(\mathrm{C}_{169}, \mathrm{H}_{192}, \mathrm{~F}_{5}, \mathrm{~N}_{15}, \mathrm{O}_{71}\right)$ and $\left(\mathrm{C}_{118}, \mathrm{H}_{144}, \mathrm{~F}_{2}, \mathrm{~N}_{6}, \mathrm{O}_{62}\right)$ $\mathrm{H}^{+}$respectively.

\section{Mechanism of solubility}

Solubility enhancement is important factor to desire therapeutic effectiveness and concentration of drug is systemic movement for pharmacological response. ${ }^{17}$ the solubility of the norfloxacin highly depend the nature of the solvent. It is almost insoluble in water, alcohol like solvents and shows highest solubility $(40 \mathrm{mg} / \mathrm{mL})$ at $\mathrm{pH} 4-5$. Earlier reports in the literature also expose that the solubilisation of norfloxacin drug or $\mathrm{HCl}$ bounded norfloxacin in quite a few solvents such as methanol, 2-propanol, etc, is difficult at $27^{\circ} \mathrm{C}$ and also at elevated temperature. ${ }^{18}$ Norfloxacin was usually used as an oral treatment for several years. A few previous report are available where norfloxacin is incorporated in various polymer matrices and delivery studies have been carried out. ${ }^{19,20}$ No studies so far have addressed the possi-bility for the topical application of newly synthesized norfloxacin based system with biocompatible, biodegradable and antibacterial activity.

Synthesized compound absorption strongly depend the solubility, potency and permeability interaction are essential to develop biological potential of novel compounds. Lipinski et al previously reported that from the commercially available drugs, $87 \%$ of the drug solubility is greater than $65 \mu \mathrm{g} / \mathrm{mL} .{ }^{21}$ They consider that solubility is not likely to limit bioavailability for an orally administered drug with a dose of $1 \mathrm{mg} / \mathrm{kg}, 65 \mu \mathrm{g} / \mathrm{ml}$ solubility are require to average drug permeability, but bioavailability is limited to solubility is less than 20 $\mu \mathrm{g} / \mathrm{mL} .{ }^{22}$ According to FDA, the aqueous solubility of drug is consider low, their aqueous solubility in $250 \mathrm{~mL}$ of $\mathrm{pH} 1-7.5$ aqueous solution is less than the amount contain in a tablet or capsule with the over dosage. Also, according to Biopharmaceutical Classification System (BCS) guidelines, this defines four classes of compounds based on both solubility and choosing permeability.

The discharge rate of norfloxacin from constructed dendrimer structure was determined by using absorption spectrometry. Effect of $\mathrm{pH}$ and concentration bring significant change in properties, and indeed, drug solubility and the solubility improvement of a drug increases the odds of successful formulations later in development. ${ }^{23-32}$ Therefore screening and 
determining aqueous solubility is one of the most essential steps in drug detection and progress.

A class drugs (solubility $100 \mu \mathrm{g} / \mathrm{mL}$, high permeability) would greatly improve the bioavailability of the compound. ${ }^{33}$ The assays and their focal point differ with various phase. It was illustrated with fluoroquinolones drug piperazine ring secondary amine group involved chemical modification. The synthesized polymeric structure of norfloxacin system maintain comparable properties of the parent fluoroquinone, without necessitate of intracellular cleavage and discharge of antibiotic.

The polymeric structures of norfloxacin dendrimer solubility differ with different $\mathrm{pH}$ solvent and it is very less soluble in neutral $\mathrm{pH}$ water and alcohol. We can use various buffer solutions to find out solubility purpose. If we are decreasing the range of $\mathrm{pH}$ from 7 to 1 drug solubility is found to increasing and this is corresponds to the hydrochloride form of norfloxacin. Buffer solutions were prepared from $0.1 \mathrm{~m}$ $\mathrm{HCl}$ with $0.1 \mathrm{~m}$ sodium bicarbonate solution and the $\mathrm{pH}$ value are adjusted with hydrochloric acid $(\mathrm{HCl})$.

\section{Drug release studies of compound 3 and 6}

Drug release from the designed system is determined by UV spectrometry with different $\mathrm{pH}$ solution and found to give different intensity of the drug concentration. Different $\mathrm{pH}$ solution prepared such as $\mathrm{pH} 1, \mathrm{pH} 2 \mathrm{pH} 3, \mathrm{pH} 4, \mathrm{pH} 6$ and $\mathrm{pH} 7$ by the adjustment of stock solutions, $\mathrm{pH} 1$ buffer solution give higher absorption intensity due to increasing drug release with respect to the increasing acidity.

The microbiological evaluation shows that the discharge of norfloxacin possesses antimicrobial activity. The drug-delivery behaviour of the system was studied to expose the potential use as a drug liberation system. The outcome shows that the norfloxacin release rates of the $\beta-C D+N O R$ complex could be controlled by the drug loading substance and the liberate medium. Representative examples for amphiphilic drug delivery system as nanocarriers based cyclodextrin are cyclodextrin conjugate, cyclodextrin inclusion complex and pseudopolyrotaxane. Hydrolysis studies were carried out to assess the norfloxacin release from macrocycle $\beta$-cyclodextrin under diverse conditions. The in vitro drug release study was investigated by incubation in buffer solution of $\mathrm{pH} 1,2,3,4,6$ and 7 , an indicator of this is in the lower $\mathrm{pH}$ of higher efficiency compared to neutral $\mathrm{pH}$ value (7). The release rate is highly dependent of the ester segment in the drug delivery system against the $\mathrm{pH}$ of the medium. Kinetics and mechanistic studies of the biodegradation of polyester is still under investigation and we intend to present and to discuss those findings in a future report. Hydrolysis studies were carried out to evaluate the norfloxacin liberate from the macromolecule in different $\mathrm{pH}$ conditions. The collective $\%$ of linked drug discharge from the system is revealed in Fig. 2. The delivery system undergoes faster norfloxacin release at lower $\mathrm{pH}$ with respect to time. At pH-7, only $20 \%$ of drug was released in 14 $\mathrm{h}$ and about $50-60 \%$ drug was released in $14 \mathrm{~h}$ at $\mathrm{pH}-4$ and 6 . However, the drug released at $\mathrm{PH}^{-1}$ in 14 $\mathrm{h}$ is about $98 \%$. The hydrolysis of drug at lower $\mathrm{pH}$ is rapid and drug release also very fast. The hydrolytic degradation of the drug candidate may also taking place by the cleavage of amide linkage. The above results showed that the drug release is very high at the gastric fluid $\mathrm{pH}$ (1.5) in controlled manner. The amount of released norfloxacin from the system was determined by uv spectra at $280 \mathrm{~nm}$, found to result a standard curve by plotting concentration versus absorption (Figure 3).

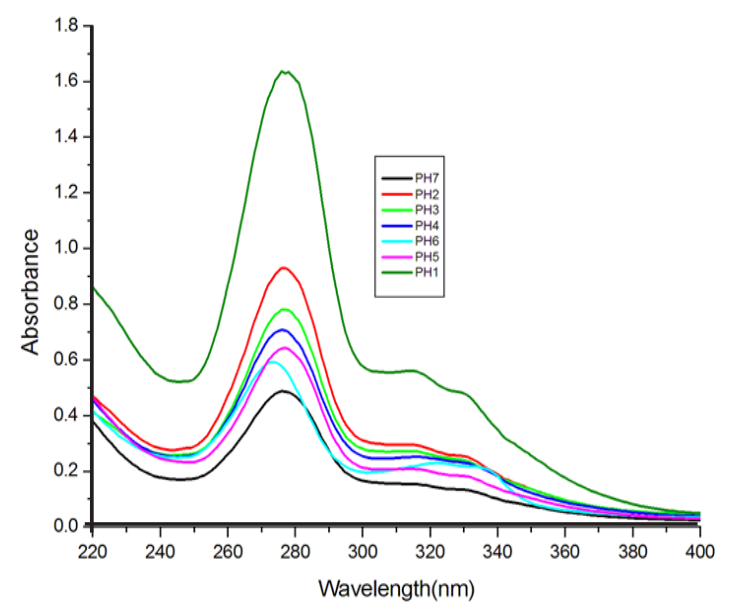

Fig. 4. Cumulative \% release of norfloxacin from compound 3 ( $\beta$-cyclodextrin core drug 


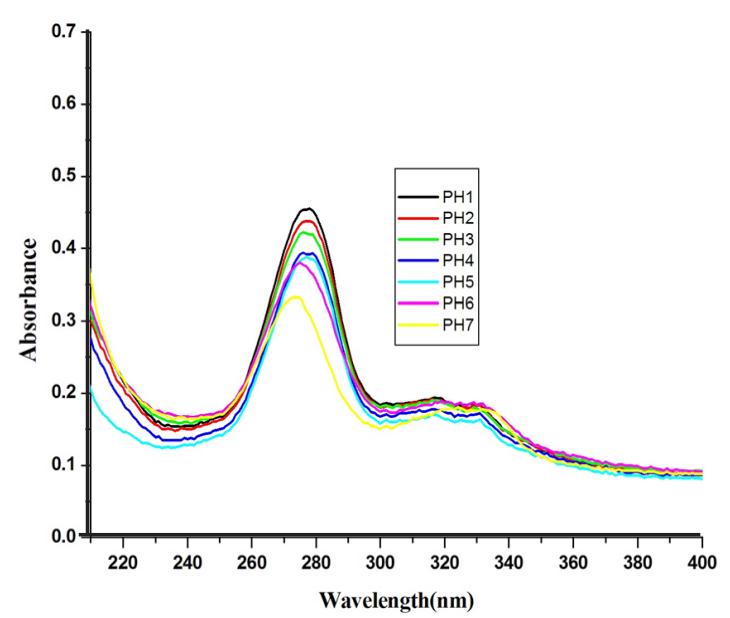

Fig. 5. Cumulative \% release of norfloxacin from compound 6 ( $\alpha$-cyclodextrin core drug delivery system)

As expected, the sustained drug delivery of synthesized polymer structure directly related to solubility and in the $\mathrm{pH}^{1}$ buffer solution gives higher absorption intensity due to increasing drug solubility. Within $14 \mathrm{~h}$ the quantity of drug fully functionalized. The uv spectrum conformed that $\beta$-cyclodextrin drug delivery system have more difference between $\mathrm{pH} 1$ and $\mathrm{pH} 7$ than $\alpha$-cyclodextrin. $\beta$-cyclodextrin drug delivery system is increasing drug delivery on decreasing $\mathrm{pH}$ order and the $\beta$-cyclodextrin is more convenient to be as good sustain drug delivery system than $\alpha$-cyclodextrin.

\section{In vitro antibacterial studies}

The anti microbiological studies are measure of relative potency and activity of compounds against microorganism under suitable condition. Two different methods are adopted to screen the above assay via disc diffusion and two-fold serial dilution.

\section{Preparation of media}

Growth of the microorganisms depends on favourable environment. Nutrient broth was used to significant cultivation of given microorganism. Agar liquid was prepared from by adding $24 \% \mathrm{w} / \mathrm{v}$ agar in the nutrient broth for making agar slants. Media is a nutritional requirement and then supplies the essential nutrients in the proper form and proportion in a culture media. Bacteria were subculture from suitable nutrient slants. The inoculams was prepared by transferring loopful of the related test organism from the stock bacteria culture into the sterile broth and incubated at $37^{\circ} \mathrm{C}$ for bacteria species such as Staphylococcus aureus (mtcc 737), Bacillus subtilis (mtcc 2063), Escherichia coli (mtcc-443), Pseudomonas aeruginosa (mtcc 741) and Proteus mirabilis (mtcc425). Each petri dish plats contain 20 $\mathrm{mL}$ of sterile nutrient agar media and added $2 \mathrm{~mL}$ of $24 \mathrm{~h}$ broth culture if bacteria were, then added to the relevant plates and mixed carefully by rotatory motion of the plates. The synthesized dendrimers were dissolved in DMSO media in the concentration of $10 \mathrm{mg} / \mathrm{mL}$ and this was maintained as stock solution. The various concentrations (100, 200 and $500 \mathrm{ppm}$ ) has been prepared from the stock solution. A sterile paper disk of $5 \mathrm{~mm}$ diameter was saturated with agar plates. The Petri dish plate were incubated with $37^{\circ} \mathrm{C}$ and the zone of inhibition was calculated excluding the disc diameter of the paper discs $(5 \mathrm{~mm})$ control discs were performed with sterile water.

\section{Anti bacterial activity}

The norfloxacin surface moiety biological ability was investigated through their in vitro antibacterial ability against various Gram-positive and Gram-negative, the Gram-positive bacterial strains like Staphylococcus aureus (mtcc 737), Vibrio cholerae (mtcc-3906) and Bacillus subtilis (mtcc 2063) and the Gram-negative bacterial species like Escherichia coli (mtcc-443, Klebsiella pneumonia, Salmonella typhi at a concentration of $100 \mu \mathrm{g} / \mathrm{mL}$ by standard cup plate method and the results, in fact, were compared with a standard drug (Ciprofloxacin).

Table 2: In vitro antibacterial activity of compound 3 (Zone of inhibition in $\mathrm{mm}$ )

Name of ppm Staphylococcus aureus Vibreo cholera Bacillus subtilis Escherichia coli Klebsiella pneumonia Salmonella typhi the organism

\begin{tabular}{llllllll}
\hline Compound 3 & 100 & 30.4 & 30.6 & 31.6 & 32.4 & 30.1 & 31.4 \\
Ciprofloxacin & 500 & 10.4 & 10.5 & 10.8 & 10.2 & 10.6 & 10.8 \\
\hline
\end{tabular}


About $20 \mathrm{ml}$ of liquid agar media freshly prepared and poured into each petridish plate and this plate keep in incubater at $37^{\circ} \mathrm{C}$ for $1 \mathrm{hrs}$, after $1 \mathrm{hrs}$ dried and the microorganism was added to each petridish plate. An L-shaped spreader was used to spread the standardized culture of microorganism on each petridish. Cups size approximately $6 \mathrm{~mm}$ diameter cupe were prepared in petridish using sterile cork borer and then labelled. DMSO solvent negative control is also to see the effect of solvent on the growth of the microbes. Dimethylsulfoxide solvent is used to prepare the test solution and standard ciprofloxacin solution $(100 \mu \mathrm{g} / \mathrm{mL})$. The prepared test solution is added to each cup in petridish plate and kept aside in an asidein an aseptic area for $1 \mathrm{~h}$ to allow diffusion of the drug sample followed by incubation at $37^{\circ} \mathrm{C}$ for 24 hour. The zone of inhibition diameter (in $\mathrm{mm}$ ) was measured and the results are given the Table 2 . Broth dilution method was investigated to evaluate the MIC of selected compounds that inhibited growth of at least one microorganism as per the standard procedure. ${ }^{34}$

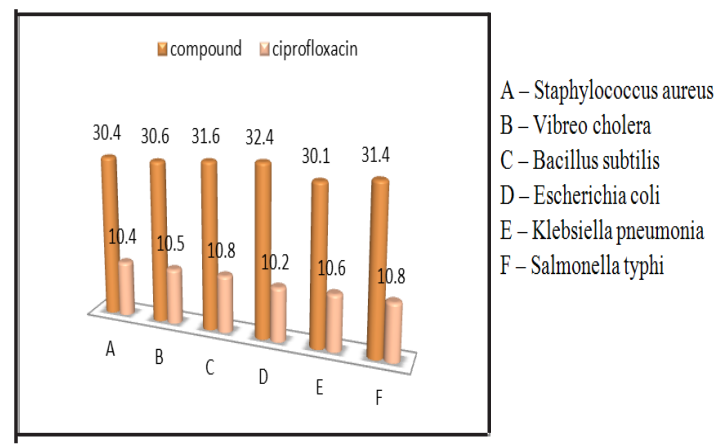

Fig. 6. Antibacterial activities of compound 3 (zone of inhibition methods)

Victorious foreword of biologically applicable piperazine ring in some of our previous cases act as important core moiety to produced the higher generation dendrimer through the bond formation between norfloxacin and macromolecule. ${ }^{35}$ Here with, we focus on norfloxacin piperazin ring bonded novel drug delivery system synthesis, $\beta$-cyclodextrin drug delivery system with twenty one norfloxacin molecule as a outside moiety and also screened for their in vitro antibacterial activity against six strains (three Gram-positive and three Gram-negative). The zone of inhibitions of the synthesized system 3 is higher than that of ciprofloxacine against different bacteria specieses. Similarly the Escherichia coli zones of inhibition values are very high compared with other bacterias. The zone of inhibition values are given in Fig. 2. The remaining bacterial organism's zone of inhibition values are shown in the Table 2. The final synthesized system 3 showed significant activity against Staphylococcus aureus (mtcc 737), Vibrio cholera (mtcc-3906), Bacillus subtilis (mtcc 2063) (Gram-positive) and Escherichia coli (mtcc443), Klebsiella pneumonia, Salmonella typhi (Gram-negative). The compound 3 was found the excellent antibacterial activity against total tested organisms. Fig.5 show that the minimum inhibition properties are at low concentration of $0.830 \mu \mathrm{g} / \mathrm{mL}$ ${ }^{1}$ against staphylococcus aureus, at $0.950 \mu \mathrm{g} / \mathrm{mL}^{-1}$ vibreo cholera, at $1.050 \mu \mathrm{g} / \mathrm{mL}^{-1}$ against Bacillus subtilis, at $0.925 \mu \mathrm{g} / \mathrm{mL}^{-1}$ against Escherichia coli, at $0.975 \mu \mathrm{g} / \mathrm{mL}^{-1}$ against Klebsiella pneumonia and at $1.090 \mu \mathrm{g} / \mathrm{mL}^{-1}$ against Salmonella typhi due to this dendrimer's twenty one molecules of norfloxacin drug. The MIC values are given in Table 3 . It is obvious that the inhibitory effects of the compound 3 more potent than the standard.

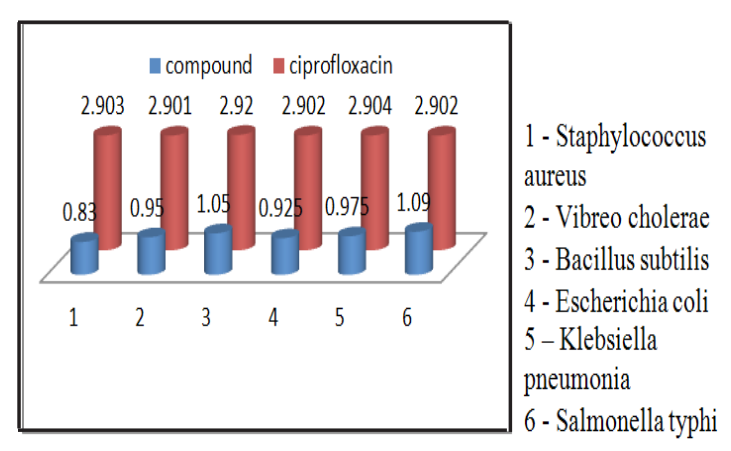

Fig. 7. Anti bacterial activities of compound 3 (minimum inhibition methods)

Table 3: In vitro antibacterial activity of compound 3 (minimum inhibition concentration $\left(\mu \mathrm{g} / \mathrm{mL}^{-1}\right)$ )

Name of Staphylococcus aureus Vibreo cholerae Bacillus subtilis Escherichia coli Klebsiella pneumonia Salmonella typhi the organism

\begin{tabular}{|c|c|c|c|c|c|c|}
\hline Compound 3 & 0.830 & 0.950 & 1.050 & 0.925 & 0.975 & 1.090 \\
\hline Ciprofloxacin(std) & 2.903 & 2.901 & 2.920 & 2.902 & 2.904 & 2.902 \\
\hline
\end{tabular}


MTT based cell viability assay for compound 3 (Norfloxacin based $\beta$-cyclodextrin core drug delivery system)

The MTT assay is a colorimetric assay for measuring cell viability through increased metabolism of tetrazolium salt (Moshmann, 1983). Cultured Escherichia coli, Staphylococcus aureus were taken into 96 well plates. Then the cells were treated with different concentration of norfloxacin dendrimer $(5,15,25,50,75$ and $100 \mu l)$ and ciprofloxacin $(100 \mu \mathrm{l})$ were incubated at $37^{\circ} \mathrm{C}$ for $12,24,48$ and 72 hour. The MTT $(0.5 \mathrm{mg} / \mathrm{ml})$ was added to the cells and then further incubated for another 3 hour. The cells were centrifuged for $10 \mathrm{~min}$ and the supernatant was removed, $200 \mu \mathrm{l}$ of dimethyl sulfoxide (DMSO) were added into each tubes. Absorbance was measured in a microplate reader at $560 \mathrm{~nm}$.

\section{DISCUSSION}

Antibacterial activity of norfloxacin measured by MTT assay in E.Colicells (Table 4 and Fig. 6 ) show the cytotoxic effect of various concentrations $(5,15$, $25,50,75$ and $100 \mu$ l) of norfloxacin drug delivery system in E. coli cells. Among the four different time duration, $72 \mathrm{~h}$ of norfloxacin dendrimer showed a maximum antibacterial activity when compared to others in E.colicells. The $\mathrm{IC}_{50}$ value was found to be $75 \mu \mathrm{L}$ concentrations.

Table 4: cytotoxicity effect of compound 3 in E. coli cells by MTT assay

\begin{tabular}{|c|c|c|c|c|c|c|c|c|}
\hline \multirow[t]{2}{*}{ Incubation time $(h)$} & \multirow[t]{2}{*}{ Control (\%) } & \multirow[t]{2}{*}{ Cip (\%) } & \multirow[b]{2}{*}{$5 \mu \mathrm{l}$} & \multicolumn{5}{|c|}{ Norfloxacin dendrimer (\%) } \\
\hline & & & & $15 \mu \mathrm{l}$ & $25 \mu \mathrm{l}$ & $50 \mu \mathrm{l}$ & $75 \mu \mathrm{l}$ & $100 \mu \mathrm{l}$ \\
\hline 12 & 100 & 90.3245 & 99.975521 & 99.75134 & 98.51487 & 97.86580 & 97.25099 & 94.85149 \\
\hline 24 & 100 & 89.2671 & 99.150623 & 99.11515 & 98.70908 & 89.57513 & 84.13306 & 75.2651 \\
\hline 48 & 100 & 91.3462 & 98.675351 & 95.72077 & 93.71297 & 86.87517 & 82.57885 & 73.56674 \\
\hline 72 & 100 & 90.2345 & 94.521720 & 86.13485 & 82.95809 & 75.41404 & 53.64531 & 40.82042 \\
\hline
\end{tabular}

Values are expressed as the mean \pm SD of three experiments in each group

The norfloxacin dendrimer exhibited significant antibacterial property in Staphylococcus aureus measured by MTT assay. Effect of Norfloxacin dendrimer cytotoxicity in Staphylococcus aureus showed a different concentration manner (Table 5 and Fig. 7). It has been noticed that the 72 and 48 hrs showed a maximum cytotoxicity against staphylococcus aureus. The $\mathrm{IC}_{50}$ value of norfloxacin was found to be 50 and $100 \mu \mathrm{L}$ concentrations.

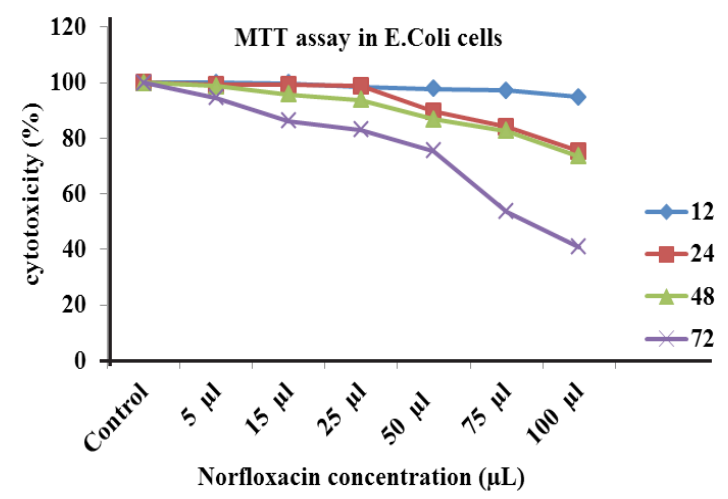

Data expressed as mean \pm SD of three experiments in each group

Fig. 8. Cytotoxicity effect of compound 3 in E. coli cells by MTT assay
Values are expressed as the mean \pm SD of three experiments in each group

The results of cell viability determination were performed by MTT assay technique showed that the synthesized test compound has remarkable activities against Escherichia coliand Staphylococcus aureus. Therefore, they could be introduced as newly synthesized antibacterial agents against commonly occurring microorganism. Moosavy et al., 2008, Fazeli et al., 2007, Misaghi and Akhondzadeh. ${ }^{36,37}$ were previously reported that the antibacterial activities of some compound. Antibacterial agent tested with various microorganisms such as Salmonella. typhimurium, Staphylococcus aurous and Bacillus cereus in a food model system and in brain heart infusion (BHI) broth.

The current study was illustrating the long time biological efficiency of newly synthesized dendrimer by MTT assay technique. Viable cell percentage changes with respect to different time duration against various concentrations. This result conforms that the sustain delivery of norfloxacin from system. E coli cell viability calculated after incubation with dendrimer for 12, 24, 48 and $72 \mathrm{~h}$ and the data are given Table 4. After $12 \mathrm{~h}$ incubation the cell viability is 94.25 for $100 \mu$ l only 5.75 percentage 
bacteria killed by test compound. After $24 \mathrm{~h}$ incubation the cell viability of $E$ coli 75.26 only 24.74 killed. For $48 \mathrm{~h} 100 \mu \mathrm{l}$ show 73.57 cell viable 26.43 percentage only killed. For $72 \mathrm{~h} 100 \mu \mathrm{l}$ show 40.82 percentage cell viable 59.82 percentage are killed. The slow decrease in the cell viability conformed sustain delivery of synthesized system. Drug delivery time and concentration is as show in the Figure 6.

Table 5: cytotoxicity effect of compound 3 in Staphylococcus aureuscells by MTT assay

\begin{tabular}{ccccccccc}
\hline Incubation time (h) & Contro l(\%) & \multirow{2}{*}{ Cip (\%) } & \multicolumn{7}{c}{ Norfloxacin dendrimer (\%) } \\
& & & $5 \mu \mathrm{l}$ & $15 \mu \mathrm{l}$ & $25 \mu \mathrm{l}$ & $50 \mu \mathrm{l}$ & $75 \mu \mathrm{l}$ & $100 \mu \mathrm{l}$ \\
\hline \multirow{2}{*}{12} & 100 & 90.0164 & 99.97552 & 97.40176 & 89.70395 & 82.90682 & 78.37605 & 73.31369 \\
24 & 100 & 91.2067 & 94.69339 & 91.352 & 86.66707 & 74.39486 & 69.24674 & 62.67624 \\
48 & 100 & 91.3672 & 91.56205 & 89.30227 & 83.35587 & 73.78682 & 64.91791 & 41.41115 \\
72 & 100 & 90.2316 & 91.86951 & 85.24783 & 66.0488 & 39.99823 & 31.63199 & 23.73725 \\
\hline
\end{tabular}

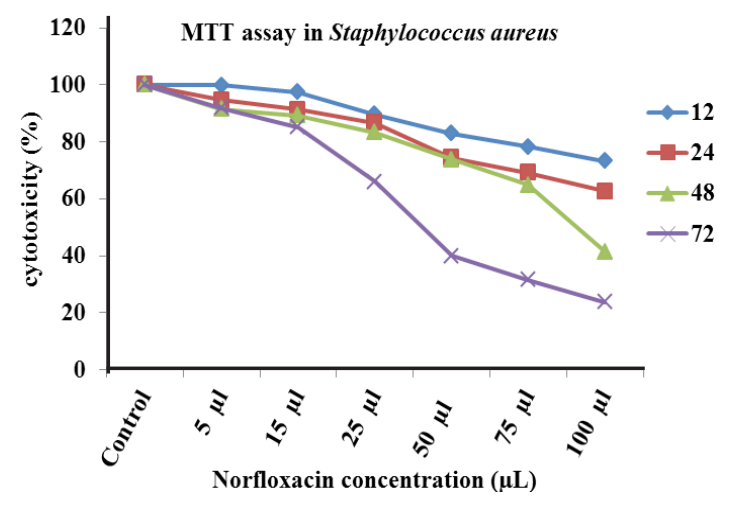

Fig. 9. cytotoxicity effect of compound 3 in Staphylococcus aureus cells by MTT assay

Norfloxacin system performed with Staphylococcus aureus to prove the control drug delivery. It is incubated on $12,24,48$ and $72 \mathrm{~h}$ with different concentration 5, 15, 25, 50, 75 and 100 $\mu \mathrm{l}$, viable cell percentage differ with respect treated drug concentration. For 12 h $100 \mu$ give 73.3 percentage viable cells, 26.7 percent only killed by norfloxacin dendrimer. After 24 hrs incubate at 100 $\mu \mathrm{l}$ show $62.7 \%$ viable cells, $37.3 \%$ only killed. After $48 \mathrm{~h}$ at $100 \mu \mathrm{l}$ show 41.4 percent viable cell. $58.6 \%$ are killed by drug releases. For $72 \mathrm{~h}$ at $100 \mu \mathrm{l}$ show 23.7 percent viable cells, 76.3 percent are killed, this result explicit sustain drug delivery of norfloxacin delivery system. Viable cell reduced with increasing incubation time and increasing concentration and the result are given in Table 5. The death percentage of cells for each hour with concentration is given in the Fig. 7. Results are compared with standard drug.

MTT based cell viability assay for compound 6 (Norfloxacin based $\alpha$ core drug delivery system)

Various concentration of $(5,15,25,50,75$ and $100 \mu \mathrm{l}$ ) compound 6 ( $\alpha$-cyclodextrin core drug) treated with Escherichia coli species, Cell viability significantly reduced by concentration 50,75 and $100 \mu \mathrm{l} . \mathrm{IC}_{50}$ value found to be concentration 25 $\mu \mathrm{l}$ at $24 \mathrm{~h}$ and given Fig.7. Compound 6 reduces the cell viability significantly from $24 \mathrm{~h}$ after that the cell viability increasing to 48 and 72 hours. viability of Escherichia coli upto 31.6 and $28.6 \%$ at $24 \mathrm{~h}$ incubation with 75 and $100 \mu \mathrm{l}$ concentration, the same concentration after 48 and $72 \mathrm{~h}$ viability increasing to 64.8 and $60.2 \%$, as mentioned in the Table 7 . These results reveal that the $\alpha$-cyclodextrin core drug delivery system hasn't long term activity due to sudden releases of drug unit.

Table 6: cytotoxicity effect of compound 6 in E. coli cells by MTT assay

\begin{tabular}{ccccccrrr}
\hline $\mathrm{T}(\mathrm{h})$ & Ctrl & Std & \multicolumn{5}{c}{ Concentration $(\mu \mathrm{l})$} \\
& & & 5 & 15 & 25 & 50 & 75 & 100 \\
\hline $12 \mathrm{~h}$ & 100 & 61.73395 & 64.88412 & 59.12361 & 55.59152 & 52.17890 & 48.98358 & 45.03259 \\
$24 \mathrm{~h}$ & 100 & 56.91428 & 63.57932 & 55.216 & 48.07273 & 42.91566 & 31.63199 & 28.60258 \\
$48 \mathrm{~h}$ & 100 & 87.72871 & 86.02865 & 80.31883 & 77.43022 & 70.06951 & 64.80476 & 60.29364 \\
$72 \mathrm{~h}$ & 100 & 89.38567 & 92.14360 & 89.96143 & 88.72496 & 86.11791 & 83.54512 & 80.16662 \\
\hline
\end{tabular}

Values are expressed as the mean $\pm S D$ of three experiments in each group 


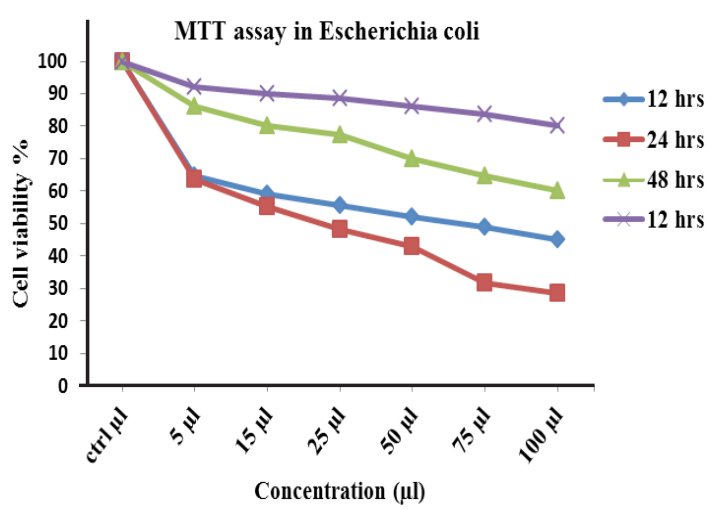

Fig. 10. cytotoxicity effect of compound 6 in E. coli cells by MTT assay
Values are expressed as the mean \pm SD of three experiments in each group

The $\mathrm{IC}_{50}$ value found to be $50 \mu \mathrm{l}$ at $24 \mathrm{~h}$ on Staphylococcus aureus as shown in the Fig.8. Compound 6 reduce the cell viability significantly from $24 \mathrm{~h}$ after the the cell viability increasing to 48 and $72 \mathrm{~h}$ viability of Staphylococcus aureus upto 44.1 and 47.7 $\%$ at $24 \mathrm{~h}$ incubation with 75 and $100 \mu \mathrm{l}$ concentration, after 48 and $72 \mathrm{~h}$ at the same concentration the cell viability increased to 58.62 and $53.28 \%$ (Table 8), from this results $\alpha$-cyclodextrin core system only active up to $24 \mathrm{~h}$ so $\alpha$-cyclodextrin not convenient to design as sustain drug delivery systems.

Table 7: Cytotoxicity effect of compound 6 in Staphylococcus aureuscells by MTT assay

\begin{tabular}{|c|c|c|c|c|c|c|c|c|}
\hline \multirow[t]{2}{*}{$\mathrm{T}(\mathrm{h})$} & \multirow[t]{2}{*}{ Ctrl } & \multirow[t]{2}{*}{ Std } & \multicolumn{5}{|c|}{ Concentration $(\mu \mathrm{l})$} & \multirow[b]{2}{*}{100} \\
\hline & & & 5 & 15 & 25 & 50 & 75 & \\
\hline $12 \mathrm{~h}$ & 100 & 65.45035 & 61.66549 & 59.89519 & 56.47952 & 53.17963 & 50.81055 & 68.9145 \\
\hline $24 \mathrm{~h}$ & 100 & 61.59068 & 58.01998 & 54.71916 & 51.77216 & 47.75287 & 44.10301 & 47.6965 \\
\hline $48 \mathrm{~h}$ & 100 & 74.12499 & 71.17041 & 67.56151 & 64.45963 & 60.93185 & 58.62305 & 53.28601 \\
\hline $72 \mathrm{~h}$ & 100 & 95.81835 & 92.34396 & 85.90499 & 79.245 & 72.50545 & 69.70001 & 73.04936 \\
\hline
\end{tabular}

Values are expressed as the mean \pm SD of three experiments in each group

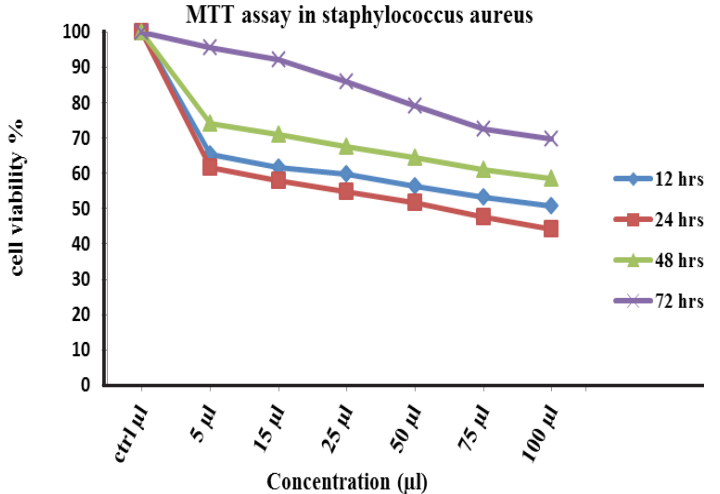

Values are expressed as the mean \pm SD of three experiments in each group

Fig. 11. Cytotoxicity effect of compound 6 in Staphylococcus aureus cells by MTT assay

\section{CONCLUSION}

The synthesised $\beta$-cyclodextrin core drug delivery system have long time activity due to their sustain releases of norfloxacin unit is identified by MTT assay method and the results proved that the drug delivery system reduced the cell viability of Escherichia coliand Staphylococcus aureus species. The synthesized $\beta$-cyclodextrin core drug delivery system long time activity against both the species is found to slowly reduce the living cells from 12 to 72 hours. The $\alpha$-cyclodextrin core released drug activity against both cells is reduced the cell viability from 12 to $24 \mathrm{~h}$ after that cell viabilities are increased from 24 to 72 hours. From this result the $\beta$-cyclodextrin core system act as very good sustain drug delivery system and also it is more convenient to design.

\section{ACKNOWLEDGEMENT}

The authors express sincere thanks to the head of the Department of Chemistry, Annamalai University, Tamilnadu, India for the facilities provided to carry out this research work.

\section{REFERENCE}

1. Uekama, K.; Hirayama, F.; and Irie, T. Chem. Rev., 1998, 98, 5, 2045; Davis,
M.E. and Brewster, M.E., Nature Rev., 2004 ,

3, 1023. 
2. Uekama, K.; Minami, K.; and Hirayama, F. J. Med.Chem., 1997, 40, 7, 2755; Minami K, Hirayama F, and Uekama K. J. Pharm. Sci., 1998, vol. 87, no. 6, p. 715; Hirayama F, Kamada M, Yano H, Udo, K, Arima H, and Uekama K. J. Incl. Phenom. Macrocyc. Chem., 2002, vol. 44, p. 159; Yano H, Hirayama F, Kamada M, Arima $\mathrm{H}$, and Uekama K. J. Controlled Release., 2002, 79, (1-3), 103.

3. Kraus, T. Modified cyclodextrins with pendant cationic and anionic moieties as hosts for highly stable inclusion complexes and molecular recognition. Curr. Org. Chem., 2011, 15, 802-814.

4. DeRossi, R.H.;Silva, O.F.;Vico, R.V.; Gonzalez, C. J. Molecular organization and recognition properties of amphiphiliccyclodextrins. Pure Appl. Chem., 2009, 81, 755-765.

5. Sallas, F.; Darcy, R. AmphiphiliccyclodextrinsAdvances in synthesis and supramolecular chemistry. Eur. J. Org. Chem. M., 2008, 6, 957-969.

6. Korendovych, I. V.; Roesner, R. A.; RybakAkimova, E. V. Molecular recognition of neutral and charged guests using metallomacrocyclic hosts. Adv. Inorg. Chem., 2007, 59, 109-173.

7. Wang, M. Nitrogen and oxygen bridged calixaromatics: Synthesis, structure, functionalization, and molecular recognition. Acc. Chem. Res., 2012, 45, 182-195.

8. Thatiparti, T. R.; Shoffstall, A. J.; von Recum, H. A. Cyclodextrin-based device coatings for affinity-based release of antibiotics. Biomaterials., 2010, 31, 2335-2347.

9. Liu, Y.; Chen, Y. Cooperative binding and multiple recognition by bridged bis $(\beta$ cyclodextrin)s with functional linkers. Acc. Chem. Res., 2006, 39, 681-691.

10. Easton, C.J.; Lincoln, S. F. Chiral discrimination by modified cyclodextrins. Chem. Soc. Rev., 1996, 25, 163-170.

11. Murakami, Y.; Kikuchi, J.; Hisaeda, Y.; Hayashida, O. Artificial enzymes. Chem. Rev., 1996, 96, 721-758.

12. Walker, B. D.; Joshi, G.; Davis, A. P. Progress in biomimetic carbohydrate recognition. Cell. Mol. Life Sci., 2009, 66, 3177-3191.

13. Goldstein EJC. Am J Med., 1987, 82(6), 3.

14. Morita, Y.; Kodama, K.; Shiota, S.; Mine, T.; Kataoka, A.; Mizushima, T.;Tsuchiya, T. Antimicrob Agents Chemother., 1998, 42, 1778.
15. Wachsen, O.; Reichert, K.H.; Kruger, R.P.; Much, H.; Schulz, G. Thermal decomposition of biodegradable polyesters, 3 Studies on the mechanism of thermal degradation of oligo-Llactide using SEC, LACCC and MALDI-TOF MS. Polymer Degrad Stabil., 1997, 55, 225-231.

16. Nielen, M.W.F.MALDITOF mass spectrometry of synthetic polymers. Mass Spectrometry Rev., 1999, 18, 309-344.

17. Shine, A. J. solubilisation of poorly soluble drugs; A Review," pharmainfo. net., 2007, 5, 6.

18. Caço, A. I.; Varanda, F.; Pratas de Melo, M. J.; Dias, A. M. A.; Dohrn, R.; Marrucho I. M. Solubility of antibiotics in different solvents. Part II. Non-hydrochloride forms of tetracycline and ciprofloxacin. Ind Eng Chem Res., 2008, 47(21), 8083-8089.

19. Tsou, T. L.; Tang, S. T.; Huang, Y. C.; Wu, J. R.; Young, J. J.; Wang, H. J. Poly(2-hydroxyethyl methacrylate)wound dressing containing ciprofloxacin and its drug release studies. $J$ Materials Sci., 2005, 16, 95-100.

20. Unnithan, A. R.; Barakat, N. A.; Pichiah, P. B. et al. Wound-dressing materials with antibacterial activity from electrospun polyurethane-dextran nano-fiber mats containing ciprofloxacin $\mathrm{HCl}$. Carbohydr Polym., 2012, 90(4), 1786-1793.

21. Lipinski, C. A.; Lombardo, F.; Dominy, B. W.; Feeney, P. J. Experimental and computational approaches to estimate solubility and permeability $\mathrm{n}$ drug discovery and development settings, Adv. Drug Deliv. Rev., 1997, 23, 3-25.

22. Prentis, R. A.; Lis, Y.; Walker, S. R. Pharmaceutical innovation by the seven UK-owned pharmaceutical companies (1964-1985), Br. J. Clin. Pharmacol., 1988, 25, 387-396.

23. Kim, C. K.; Park, J. S. Solubility enhancers for oral drug delivery: canchemical structure manipulation be avoided? Am. J. Drug Deliv., 2004, 2, 113-130.

24. Chaubal, M. V. Rapid screening of excipients to develop effective formulations, Drug Deliv. Technol., 2005, 5, 40, 42.

25. Bittner, B.; Mountfield Richard, J. Intravenous administration of poorly soluble new drug entities in early drug discovery: the potential impact of formulation on pharmacokinetic 
parameters, Opin. Drug Discov. Dev., 2002, 5, 59-71.

26. Gardner, C.; Drug candidate selection: the role of physical chemistry and material science in form and formulation, Bull. Tech. Gattefosse., 2005, 9-18.

27. Carlson, E. D.; Cong, P.; Chandler Jr, W. H.; Chau, H. K.; Crevier, T.; Desrosiers, P. J.; Doolen, R. D.; Freitag, C.; Hall, L. A.; Kudla, T.; Luo, R.; Masui, C.; Rogers, J.; Song, L.; Tangkilisan, A.; Ung, K. Q.; Wu, L. An integrated high throughput workflow for preformulations: polymorph and salt selection studies, Pharma. Chem., 2003, 2, 10-15.

28. Gardner, C. R.; Almarsson, O.; Chen, H.; Morissette, S.; Peterson, M.; Zhang, H.; Wang, S.; Lemmo, A.; Gonzalez-Zugasti, J.; Monagle, J.; Marchionna, J.; Ellis, S.; McNulty, C.; Johnson, A.; Levinson, D.; Cima, M. Application of high throughput technologies to drug substance and drug roduct development, N Comput. Chem. Eng., 2004, 28, 943-953.

29. Gardner, C.R.;Walsh, C.T.Almarsson. Drugs as materials: valuing physical form in drug discovery, Nat. Rev. Drug Discov., 2004, 3 926-34.

30. Morissette, S. L.; Almarsson, O.; Peterson, M. L.; Remenar, J. F.; Read, M. J.; Lemmo, A. V.; Ellis, S.; Cima, M. J.; Gardner, C. R. High-throughput crystallization: polymorphs, salts, co-crystals and solvates of pharmaceutical solids, $A d v$. Drug Deliv. Rev., 2004, 56, 275-300.

31. Kerns, E. H. High throughput physicochemical profiling for drug discovery, J Pharm. Sci., 2001, 90, 1838-1858.

32. Lipper, R. A. How can we optimize selection of drug development candidates from many compounds at the discovery stage? Mod. Drug Discov., 1999, 2, 55-60.

33. Amidon, G. L.; Lennernaes, H.; Shah, V.P.; Crison, J. R. A theoretical basis for a biopharmaceutic drug classification: the correlation of in vitro drug product dissolution and in vivo bioavailability, Pharm. Res., 1995, 12, 413-420.

34. Sharma, K. Manual of Microbiology Tools and Techniques, $2^{\text {nd }}$ ed.; Ane's Book India: New Delhi., 2007.

35. Vembu, S.; Pazhamalai, S.; Gopalakrishnan, M. Potential antibacterial activity of triazine dendrimer: Synthesis and controllable drug release properties. Bioorganic Med Chem., 2015, 23(15), 4561-4566. doi:10.1016/j. bmc.2015.06.009.

36. Moosavy, M. H.; Akhondzadeh-Basti, A.; Misaghi, A.; Zahraei-Salehi, T.; Abbasifar R.; Ebrahimzadeh, H.; Mousavi, H. A.; Alipour, M.; Emami Razavi, N.; Gandomi, H.; Noori, N. Effect of Zataria multiflora Boiss essential oil and nisin on Salmonella typhimurium and Staphylococcus aureus in a food model system and on the bacterial cell membranes. Food Res Int., 2008, 41, 1050-1057.

37. Misaghi, A. Akhondzadeh-Basti, A. Effects of Zataria muliflora Boiss essential oil and nisin on Bacillus cereus ATCC 11778. Food Control., 2007, 18, 1043-1049. 